\title{
Metal Carbides for Biomass Valorization
}

\author{
Carine E. Chan-Thaw ${ }^{1, *}$ and Alberto Villa ${ }^{2, *}$ \\ 1 Institut pour la Maîtrise de l'Énergie, Université d'Antananarivo, BP 566, Antananarivo 101, Madagascar \\ 2 Dipartimento di Chimica, Università degli Studi di Milano, via Golgi 19, 20133 Milano, Italy \\ * Correspondence: carine.chanthaw@gmail.com (C.E.C.-T.); alberto.villa@unimi.it (A.V.); \\ Tel.: +39-02-50314361 (A.V.)
}

Received: 18 January 2018; Accepted: 7 February 2018; Published: 9 February 2018

\begin{abstract}
Transition metal carbides have been utilized as an alternative catalyst to expensive noble metals for the conversion of biomass. Tungsten and molybdenum carbides have been shown to be effective catalysts for hydrogenation, hydrodeoxygenation and isomerization reactions. The satisfactory activities of these metal carbides and their low costs, compared with noble metals, make them appealing alternatives and worthy of further investigation. In this review, we succinctly describe common synthesis techniques, including temperature-programmed reaction and carbothermal hydrogen reduction, utilized to prepare metal carbides used for biomass transformation. Attention will be focused, successively, on the application of transition metal carbide catalysts in the transformation of first-generation (oils) and second-generation (lignocellulose) biomass to biofuels and fine chemicals.
\end{abstract}

Keywords: transition metal carbides; biomass; hydrodeoxygenation; hydrogenation; isomerization

\section{Introduction}

Carbon-rich fossil feedstocks have been identified as the main resource for obtaining fuels and fine chemicals [1]. However, they are not renewable and have a non-negligible impact on environmental pollution. Human activity, such as the burning of fossil fuels and the clearing of forests, increases the total amount of greenhouse gas emissions, which in turn contributes to climate change. Worldwide demand for energy is increasing with increasing population and the improvement in economic wellbeing. Therefore, new methods for the production of energy from alternative, renewable resources must be developed. Solar, wind, hydropower and biomass are possible solutions that can satisfy the growing worldwide energy demand. Environmentally friendly biomass was demonstrated to be a valid carbon-based alternative source for the production of renewable chemicals and fuels [1-5]. Biomass can be broadly classified into two categories: first-generation and second-generation biomass. First-generation biomass materials consist of triglycerides, which are the major component of vegetable oils, waste grease, and oil-processing waste [2,3]. Second-generation biomass consists of lignocellulose, which has attracted much attention in recent decades [4-7]. Biomass must undergo several transformations in order to be converted into biofuels and fine chemicals. Systems utilizing heterogeneous catalysts have been demonstrated to be more efficient for the transformation of biomass than homogenous or enzymatic systems. Furthermore, heterogeneous catalysts are easier to recover and have a higher durability [8]. The first step of biomass transformation is depolymerization through hydrolysis to produce a mixture of oxygenate molecules. The removal of oxygen is required in order to produce fuel biomass-derived molecules with the same number of carbon atoms, because these biomass derivatives contain an large amount of oxygen, i.e., a high $\mathrm{O} / \mathrm{C}$ ratio, deoxygenation is a significant reaction [9]. The products deriving from the pyrolysis of raw biomass contain ketones, aldehydes or acids, i.e., $\mathrm{C}=\mathrm{O}$ bonds, and they need to be selectively hydrogenated (-C-O-H) to increase the stability of the oils $[10,11]$. Selective cleavage of $\mathrm{C}-\mathrm{OH}$ or $\mathrm{C}-\mathrm{O}$ bonds by dehydroxylation or deoxygenation results 
in water formation with the elimination of oxygen. Loss of carbon as $\mathrm{CO}$ or $\mathrm{CO}_{2}$ by decarbonylation or decarboxylation, respectively, is therefore avoided and results in the preservation of the number of the initial carbon atoms. One drawback of this strategy lies in the lack of hydrogen before the end of the dehydration process. To be able to further remove oxygen, additional hydrogen should be provided through hydrodeoxygenation (HDO). The desired HDO catalyst should therefore be able to selectively cleave C-O bonds without any C-C cleavage. Serrano-Ruiz and co-authors [12] and later Jae et al. [13] reported that a metal/Brønsted bifunctional catalyst fulfills the prerequisites. Metal and acid sites are responsible for the hydrogenation and the dehydration, respectively.

Up to now, mainly noble metal-based catalysts have been used for the transformation of biomass-based resources [5,6]. They have demonstrated good activity and stability under the harsh reaction conditions (acidic, basic and aqueous) required for biomass conversion. Nevertheless, noble metals have a significant cost and are they are present in limited quantity. Therefore, suitable substitutes should be found [14,15].

Transition metal carbides constitute a suitable alternative for noble metal-based catalysts [16,17]. Indeed, the utilization of these materials as a replacement for noble metal will decrease the final cost of the catalyst. For example, the cost per gram of tungsten (purity $99.5 \%$, Aldrich, Milano, Italy) and molybdenum $\left(\mathrm{Mo}_{2} \mathrm{C}\right.$, purity $99.5 \%$, Aldrich, Milano, Italy) carbides is 4 and 1 EUR respectively. On the other hand, the cost per gram of $\mathrm{Pt}$ (powder, purity 99.99\%, Aldrich, Milano, Italy), Ru (powder, purity 99.99\%, Aldrich, Milano, Italy) and Pd (foil, purity 99.9\%, Aldrich, Milano, Italy) is 291, 205 and 100 EUR, respectively. Levy and Boudart [18] reported that W-carbide and Pt have a similar electronic structure, as well as similar catalytic properties. Since then, transition metal carbide has attracted much interest in catalysis and surface science. It has been demonstrated that the catalytic properties of these cheaper metal carbides are comparable to the catalytic properties of the more expensive Pt-groups metals [19-22]. In the case of dehydrogenation, hydrogenation and hydrogenolysis, which involve a transformation of hydrocarbons' $\mathrm{C}-\mathrm{H}$ bonds, activities of these metal carbides are similar or better than the activities of Pt-group metals [19,23-25]. For example, W-carbides can substitute $\mathrm{Pt}$ in hydro-isomerization reactions [26-28], if the correct pretreatment has been applied. Carbides were reported to be highly selective in the HDO of vegetable oils, where the C-O bonds scission and maintaining the C-C bonds intact are the prerequisites [29].

Supported molybdenum carbide was reported to be active for the phenol HDO during the hydrogenation of levulinic acid to gamma valerolactone in a continuous flow liquid phase reactor [30].

For a better understanding of such promising results, accurate attention to the synthesis and characterization of these carbides is essential. The first part of this review will describe the most common techniques used to prepare metal carbides, which have been used in the transformation of biomass. The second part will be devoted to the different applications of these metal carbides in biomass transformation. The application of metal carbides in hydrogenation and hydrodeoxidation reactions of first-generation (vegetable oils) and second-generation (cellulose, hemicellulose and lignin) biomass-derived molecules will be discussed (Scheme 1). In the last paragraph, we report a few examples of carbides as catalysts for reforming reactions. 


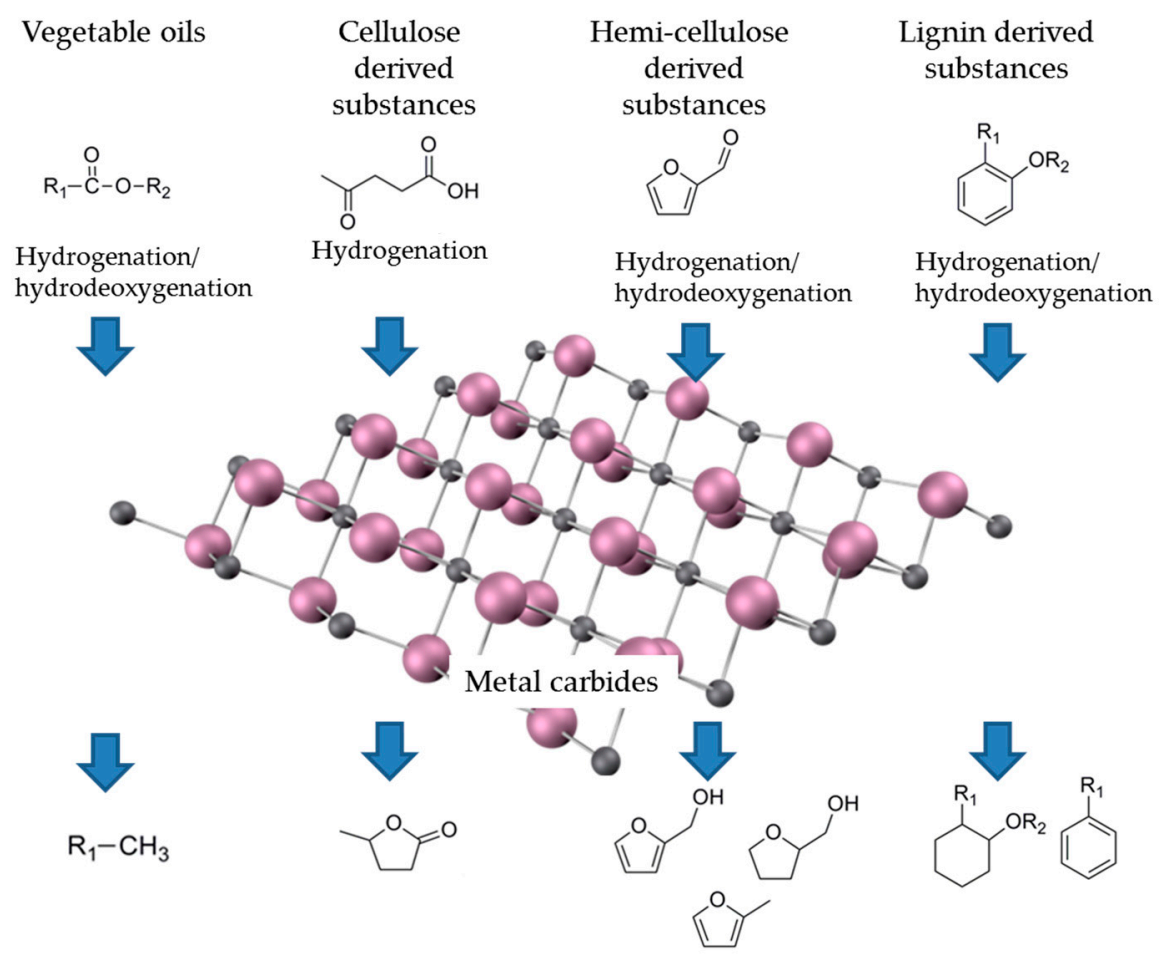

Scheme 1. Example reactions discussed in this review.

\section{Carbide Synthesis and Characterization}

Several methods for the preparation of metal carbides are reported in the literature. However, in this review we choose to focus on the following three methods; temperature-programmed reduction, ball milling and carbothermal hydrogen reduction. These methods are used most often to synthesize catalysts for biomass transformation.

\subsection{Temperature-Programmed Reduction (TPR)}

Solid-state reactions are the most direct method used to prepare metal carbides. Boudart and coworkers developed a method to prepare metal carbides using temperature-programmed reduction (TPR) [31]. This methodology consists of treating a Mo precursor under continuous $\mathrm{H}_{2} /$ hydrocarbon flow of differing compositions and different temperatures. This technique has been largely utilized to produce unsupported and supported molybdenum carbides [32,33]. Djéga-Mariadassou and coworkers studied the sequential transformation of the crystal structure of the oxide precursor from molybdic acid to $\mathrm{Mo}_{4} \mathrm{O}_{11}$ to $\mathrm{MoO}_{2}$ to $\mathrm{Mo}$ to $\mathrm{Mo}_{2} \mathrm{C}$, by X-ray diffraction (XRD) [34]. These transformations involve the sequential loss of lattice oxygen as $\mathrm{H}_{2} \mathrm{O}$ and lattice carburization via $\mathrm{CH}_{4}$.

Quiroz et al. prepared $\mathrm{Mo}_{2} \mathrm{C}$ carbide with varying sizes and shapes [35]. Well-oriented $\beta-\mathrm{Mo}_{2} \mathrm{C}$ nanoparticles with a fibril morphology were formed when carbon nanotubes (CNTs) were used as the source of carbon at $700{ }^{\circ} \mathrm{C}$ for $6 \mathrm{~h}$ under an inert environment. Well-defined $\beta-\mathrm{Mo}_{2} \mathrm{C} 1 \mathrm{D}$ nanostructures were formed after carburization of the nano-sized $\alpha-\mathrm{MoO}_{3}$ precursor at $650{ }^{\circ} \mathrm{C}$ under $\mathrm{CH}_{4} / \mathrm{H}_{2}$ atmosphere.

This technique was also employed to prepare $\mathrm{WC}_{x}$ starting from tungsten oxide precursor under similar $\mathrm{H}_{2}$ /hydrocarbon flow, but at higher temperatures [36,37].

\subsection{Ball Milling}

Ball milling is widely used to grind metal carbide precursor and prepare materials with a nanocrystalline state and good dispersion. For example, Regmi et al. prepared a carbide-phosphide composite by ball milling together $\mathrm{MoO}_{3}$ and multi-walled carbon nanotubes (MWCNTs). The catalyst 
was further calcined at high temperature $\left(950{ }^{\circ} \mathrm{C}\right)$, followed by the hydrothermal deposition of phosphide on as-synthesized carbide (Figure 1) [38].

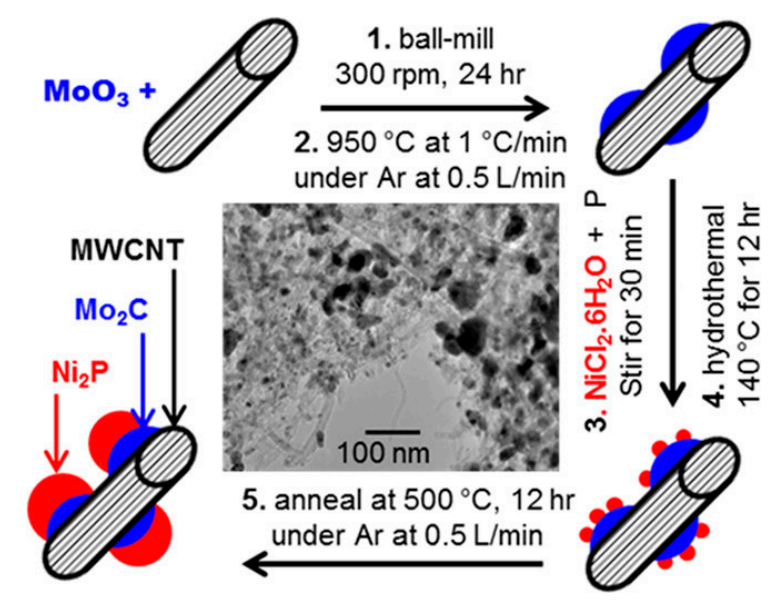

Figure 1. Sequential synthesis scheme for carbide-phosphide composite catalysts. Inset is a TEM micrograph with composite catalysts supported and dispersed on multi-walled carbon nanotubes (MWCNTs). Reprinted with permission from [38]. Copyright American Chemical Society, 2017.

\subsection{Carbothermal Hydrogen Reduction (CHR)}

$\mathrm{Mo}_{2} \mathrm{C} / \mathrm{AC}$ and $\mathrm{Mo}_{2} / \mathrm{CNTs}$ were prepared by incipient wetness impregnation using ammonium heptamolybdate. The precursors overcame a temperature-programmed carburization (TPC) under a stream of $\mathrm{CH}_{4} / \mathrm{H}_{2}$ at $650{ }^{\circ} \mathrm{C}$ [30]. Jimenez et al. prepared $\mathrm{Mo}_{2} \mathrm{C}$ carbides supported on activated carbon (AC), carbon nanofibers and carbon nanotubes, by impregnation with ammonium molybdate or molybdic acid and carbothermal hydrogen reduction at $1000^{\circ} \mathrm{C}$ [39]. The catalysts obtained showed different crystalline phases depending upon both the Mo precursor used and the support (Figure 2).

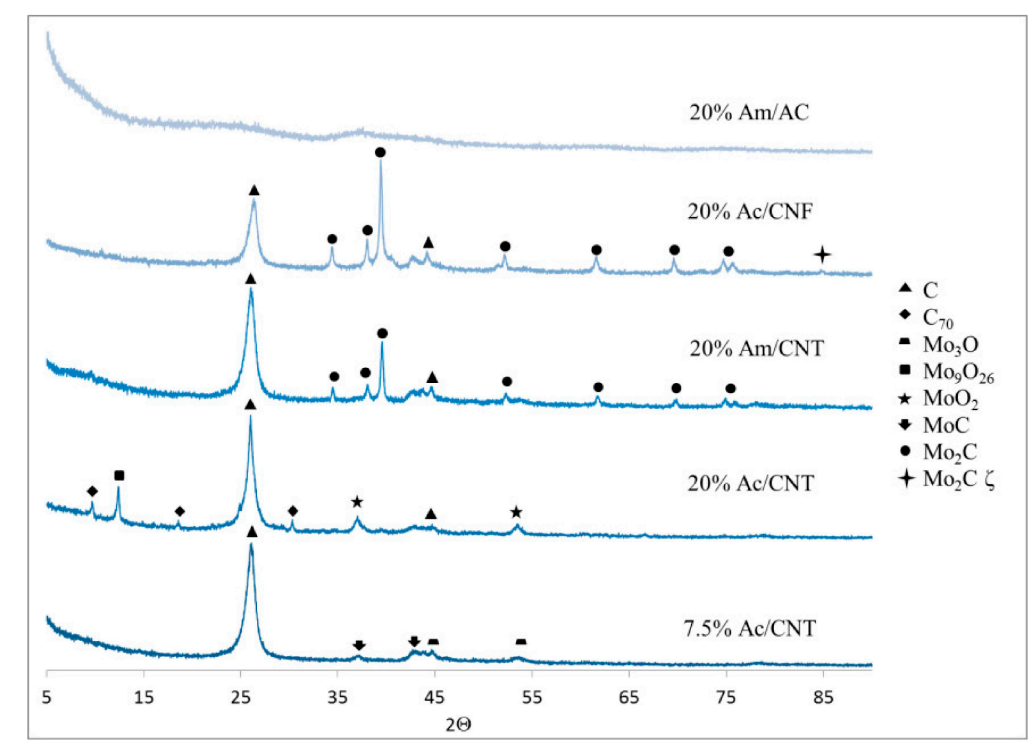

Figure 2. X-ray diffractograms of representative catalysts showing different crystalline phases, Reproduced from [39].

High-angle annular dark-field (HAADF) scanning transmission electron microscopy (STEM) was used to characterize the structure of $\mathrm{Mo}_{2} \mathrm{C} / \mathrm{CNTs}$ prepared by carbothermal hydrogen reduction [40]. 
The distribution of brighter spots indicated that the $\mathrm{Mo}_{2} \mathrm{C}$ particles (Figure 3) are uniformly dispersed on CNTs supports.
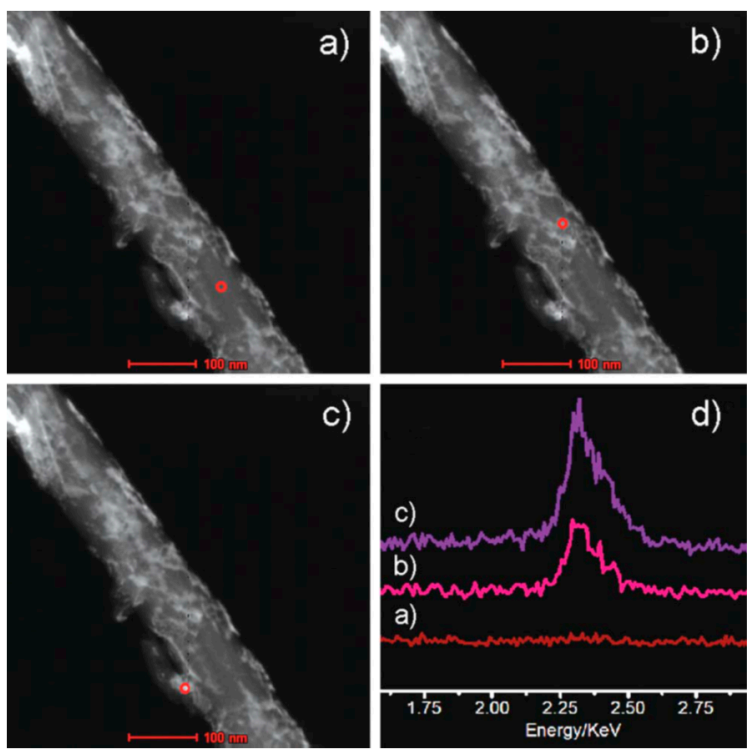

Figure 3. (a-c) High-angle annular dark-field (HAADF) images of three different sport, (d) Energy Dispersive X-ray Analysis (EDX) elemental spot-scanning profiles of the three representative spots of $\mathrm{Mo}_{2} \mathrm{C} / \mathrm{CNTs}$ catalyst. Reproduced with permission from [40]. Copyright The Royal Society of Chemistry, 2011.

CHR is the methodology used to prepare tungsten carbide using ammonium metatungstate as $\mathrm{W}$ precursor at varying carburization temperatures [41]. Ji et al. demonstrated the phase composition depends on the CHR temperature [42]. A well-crystallized and phase-pure $\mathrm{W}_{2} \mathrm{C}$ was formed only at $800{ }^{\circ} \mathrm{C}$, above which temperature a fraction of $\mathrm{W}_{2} \mathrm{C}$ was further carburized to WC (Figure 4).

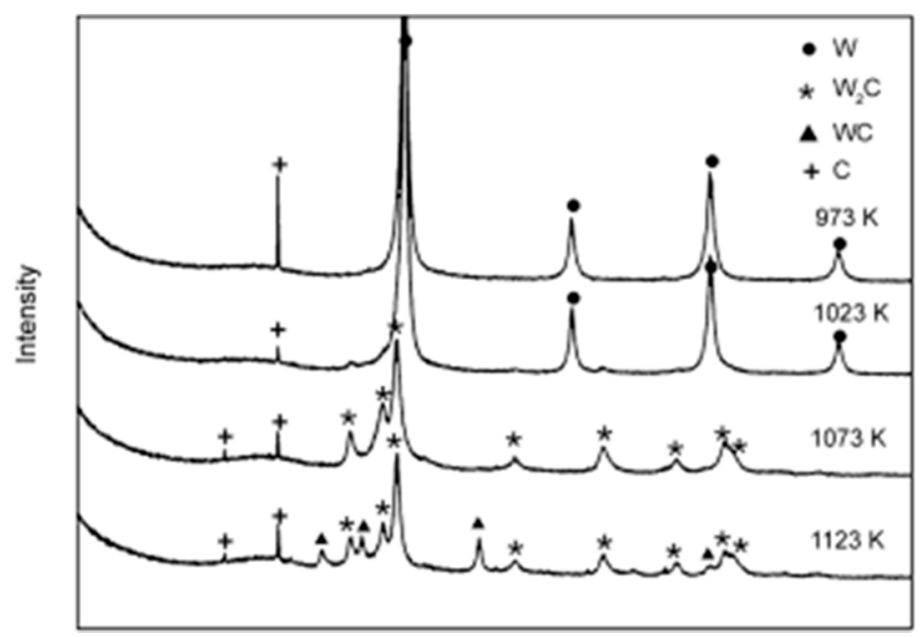

Figure 4. X-ray diffraction (XRD) patterns of $30 \% \mathrm{~W}_{2} \mathrm{C} / \mathrm{AC}$ prepared at different carbothermal hydrogen reduction temperatures. Adapted with permission from [42]. Copyright WILEY-VCH Verlag GmbH and Co. KGaA, Weinheim, 2008.

Although not mentioned here, other methods are also used to characterize the prepared carbides for reactions. Raman spectroscopy confirms the introduction of oxygen-containing functional groups on the CNTs' surface [35]. CO-pulsed chemisorption measurements, thermal gravimetric 
analysis (TGA) and differential thermal analysis (DTA) were utilized to characterize nanostructured molybdenum carbide [35]. Microcalorimetry of $\mathrm{CO}$ adsorption was performed to determine the $\mathrm{CO}$ uptake and to calculate the dispersion of active sites [43].

\section{Application in Biomass Transformation}

Biomass can be split into two categories: first-generation biomass and second-generation biomass. Both categories will be described in this section.

\subsection{First-Generation Biomass}

The pyrolysis of raw biomass results in the production of bio-oil. The hydrolysis reaction of fats and oils, also called triglycerides, results in the production of glycerol and fatty acids which are carboxylic acids characterized by a high $\mathrm{O} / \mathrm{C}$ ratio. Once the excess oxygen atoms are removed, these hydrocarbon chains, in the diesel range, constitute possible renewable feedstocks for transportation fuels. HDO reaction has thus gained much attention in making suitable triglycerides as an alternative fuel precursor to replace diesel from fossil sources.

Carbon nanotube-supported $\mathrm{Mo}_{2} \mathrm{C}\left(\mathrm{Mo}_{2} \mathrm{C} / \mathrm{CNT}\right)$ and active carbon-supported $\mathrm{Mo}_{2} \mathrm{C}\left(\mathrm{Mo}_{2} \mathrm{C} / \mathrm{AC}\right)$ catalysts were reported as active and selective in the one-step conversion of vegetable oils into branched diesel-like hydrocarbons $[40,44]$. When supported on $\mathrm{AC}, \mathrm{Mo}_{2} \mathrm{C}$ was found to be more active than the unsupported $\mathrm{Mo}_{2} \mathrm{C}$ for the $\mathrm{HDO}$ of methyl stearate, a model compound [44]. After only $1 \mathrm{~h}$ reaction, $\mathrm{Mo}_{2} \mathrm{C} / \mathrm{AC}$ reaches $65 \%$ conversion. Similar conversion (67\%) was reached with the unsupported $\mathrm{Mo}_{2} \mathrm{C}$ after $5 \mathrm{~h}$. Both catalysts led to the formation of paraffins via $\mathrm{HDO}, 42 \%$ versus $69 \%$ selectivity with $\mathrm{Mo}_{2} \mathrm{C}$ and $\mathrm{Mo}_{2} \mathrm{C} / \mathrm{AC}$, respectively. $\mathrm{Mo}_{2} \mathrm{C} / \mathrm{AC}$ was therefore utilized as catalyst for the conversion of diverse vegetable oils (such as, among others, soybean oil, rapeseed, olive oil and sunflower oil) into hydrocarbons. The highest yield of hydrocarbon was obtained with olive oil (88\%), while sunflower oil as feedstock led to a lower yield, $76 \% . \mathrm{Mo}_{2} \mathrm{C} / \mathrm{AC}$ was found to be active and stable over sixteen runs with olive oil as feedstock.

$20 \% \mathrm{Mo}_{2} \mathrm{C} / \mathrm{CNT}$ was tested and compared to $5 \% \mathrm{Pd} / \mathrm{CNTs}$ and $5 \% \mathrm{Pt} / \mathrm{CNTs}$ for the one-step hydrodeoxygenation and isomerization of vegetable oils (Scheme 2) [40]. 20\% $\mathrm{Mo}_{2} \mathrm{C} / \mathrm{CNTs}$ was more active than $5 \% \mathrm{Pd} / \mathrm{CNTs}$ and $5 \% \mathrm{Pt} / \mathrm{CNTs}(90 \%, 41 \%$ and $32 \%$, respectively) in the transformation of methyl palmitate at $240{ }^{\circ} \mathrm{C}$. The authors observed that the main reaction route of higher aliphatic esters on $\mathrm{Mo}_{2} \mathrm{C}$ is hydrodeoxygenation, compared to noble metals (Scheme 1). The authors further investigated the $\mathrm{HDO}$ of vegetable oils catalyzed with $20 \% \mathrm{Mo}_{2} \mathrm{C} / \mathrm{CNTs}$. The highest paraffin yields were obtained $(86 \%)$ when rapeseed oil was used as feedstock (Figure 5). Surprisingly, the catalyst was also selective to branched alkanes including 2-methylheptadecane, 3-methylheptadecane, 4-methylheptadecane, 8-methylheptadecane and 2,6,10-trimethylpentadecane. Branched alkanes are high-grade diesel fuels with a low freezing point. The authors postulated that the isomerization reaction of linear alkanes into branched alkanes on $\mathrm{Mo}_{2} \mathrm{C} / \mathrm{CNTs}$ catalysts was possible thanks to the structure of esters, especially the length of the carbon chains. Compared to rapeseed oil, a similar hydrocarbon yield ( $87 \%$ ) and higher branched alkane yield (55\%) were obtained with sunflower oil by reducing the mass ratio of sunflower oil with $\mathrm{Mo}_{2} \mathrm{C}$ to $7.5: 1$.

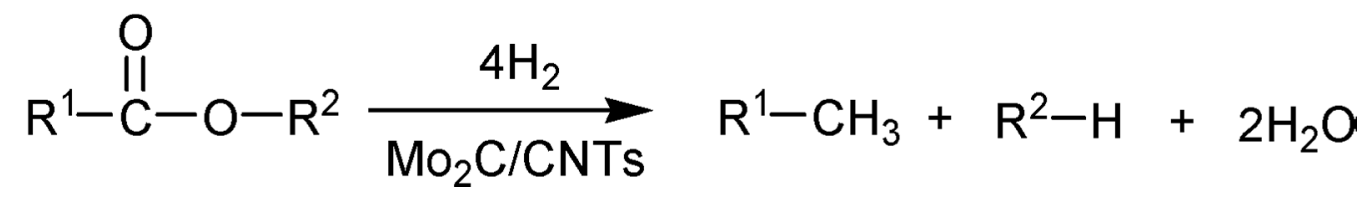

Scheme 2. Hydrodeoxygenation of higher aliphatic esters on $\mathrm{Mo}_{2} \mathrm{C} / \mathrm{CNTs}$. Reproduced with permission from [40]. Copyright The Royal Society of Chemistry, 2011. 


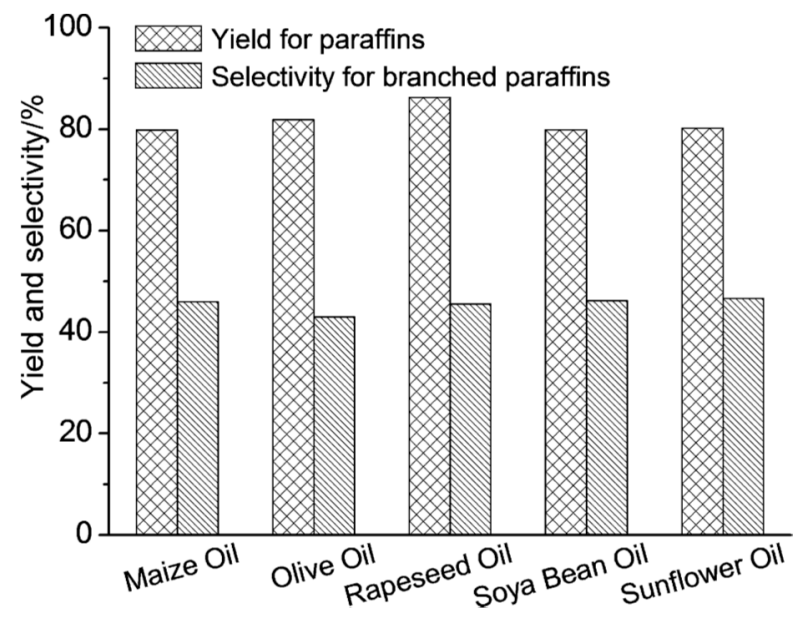

Figure 5. Yield and selectivity obtained from different vegetal oil hydrodeoxygenation. Reproduced with permission from [40]. Copyright The Royal Society of Chemistry, 2011.

$\mathrm{Mo}_{2} \mathrm{C} / \mathrm{CNT}$ exhibited better catalytic performance compared to noble metal (5\% Pd and $5 \%$ $\mathrm{Pt}$ ) supported catalysts, the classical catalyst for the transformation of the model compound methyl palmitate into hydrocarbons, (conversion of $90 \%, 41 \%$ and $32 \%$ for $\mathrm{Mo}_{2} \mathrm{C} / \mathrm{CNTs}, \mathrm{Pd} / \mathrm{CNTs}$ and $\mathrm{Pt} / \mathrm{CNTs}$, respectively) as well as a higher resistance to deactivation.

Carbon nanofibers were investigated as a support for $\mathrm{Mo}_{2} \mathrm{C}$ and $\mathrm{W}_{2} \mathrm{C}$ by Hollak et al. [45] for the hydrodeoxygenation of oleic acid. Both catalysts showed a good activity, but a different selectivity. $\mathrm{Mo}_{2} \mathrm{C} / \mathrm{CNF}$ was selective to paraffin (saturated carbon) whereas $\mathrm{W}_{2} \mathrm{C} / \mathrm{CNF}$ was more selective to olefin. Moreover, $\mathrm{Mo}_{2} \mathrm{C} / \mathrm{CNF}$ was reported more active and more stable than $\mathrm{W}_{2} \mathrm{C} / \mathrm{CNF}$.

More recently, Shi and co-authors [46] reported a theoretical study of butyric acid HDO to butane over a hexagonal $\mathrm{Mo}_{2} \mathrm{C}(101)$ surface catalyst. They proposed that the reaction starts with the butyric acid dissociation into surface $\mathrm{OH}$ and acyl species, followed by acyl hydrogenation into surface aldehyde. The butanal obtained is hydrogenated into butanol. Finally, butanol is dissociated into surface $\mathrm{OH}$ and butyl groups, which in turn are further hydrogenated into butane. The authors warn that these results are correlated only to the hexagonal phase of $\mathrm{Mo}_{2} \mathrm{C}$ and might therefore diverge from the experimental activity and selectivity. Indeed, $\mathrm{Mo}_{2} \mathrm{C}$ catalysts are made of several phases and thus display different facets and surface structure.

One concern about first-generation biomass lies in the food-chain competition. It is recommended not to divert fats and oils deriving from edible vegetables from the food chain. Attention is therefore directed to waste oil or to non-edible cellulosic resources. These latter compounds constitute second-generation biomass.

\subsection{Second-Generation Biomass}

Lignocellulose, the second-generation biomass feedstock, is composed of cellulose, hemicellulose and lignin. The transformation of each feedstock will be discussed.

\subsubsection{Cellulose}

Cellulose from plant biomass can serve as a sustainable feedstock for fuels, chemicals and polymers that are currently produced from petroleum. The efficient conversion of biomass to valuable and sustainable fuels and chemicals is still a challenge. One attractive approach lies in the transformation of cellulose into levulinic acid (LA) by acid-catalyzed hydrolysis. LA is a versatile building block containing a ketone carbonyl group and an acidic carboxyl group. When cellulose with a high $\mathrm{O} / \mathrm{C}$ ratio is transformed into fuels, an excess of oxygen must be removed. Alternatively, when cellulose is 
transformed into oxygenates, most of the oxygen-functional groups in the cellulose are preserved in the target molecule, polyols for example.

Sustainable production of fuels. LA has been accepted as a promising and sustainable platform molecule for further application in biorefineries [47]. Ideally, LA can be hydrogenated to $\gamma$-valerolactone (GVL), another platform molecule that finds application as a precursor for chemicals, solvent, fuel additives and fuel [48] (Figure 6).

Hydrogenation of levulinic acid to $\gamma$-valerolactone over supported molybdenum carbide was reported by Mai et al. [30]. For comparison, molybdenum carbide was supported on both active carbon and carbon nanotubes. The choice of alternative, cheap, non-noble catalysts was directed by the availability and price limitations of noble metal-based catalysts, which are the catalytic systems most often used for GVL production. Molybdenum carbide was chosen not only for its comparable catalytic behavior to precious metals [23,49], but also for its mechanical strength, as well as its electrical and thermal conductivity. To highlight the influence of the support during the reaction, the reaction was carried out at different temperatures $\left(100,150\right.$ and $\left.200{ }^{\circ} \mathrm{C}\right)$. The higher the temperature, the better the LA conversion with both catalysts (approximately $95 \%$ and over $99 \%$ for $20 \% \mathrm{Mo}_{2} \mathrm{C} / \mathrm{CNT}$ and $20 \% \mathrm{Mo}_{2} \mathrm{C} / \mathrm{AC}$, respectively). With $\mathrm{Mo}_{2} \mathrm{C} / \mathrm{CNT}$, better conversion was obtained (at $200{ }^{\circ} \mathrm{C}$, over $99 \% \mathrm{LA}$ conversion against $15 \%$ at $100{ }^{\circ} \mathrm{C}$ ) and the LA conversion was stable over $6 \mathrm{~h}$ in the three cases (Figure 7).

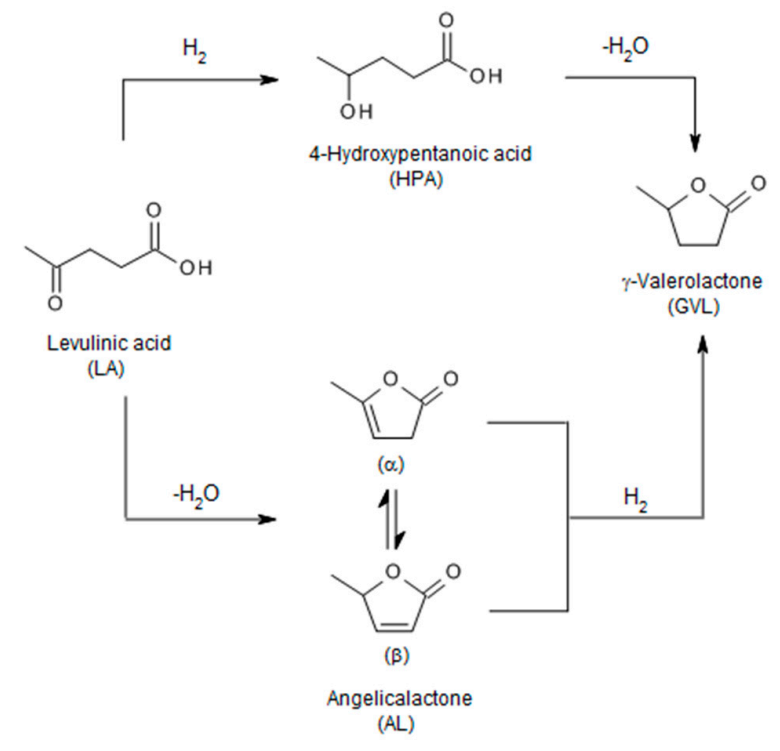

Figure 6. Overall reaction pathway to produce $\gamma$-valerolactone (GVL).
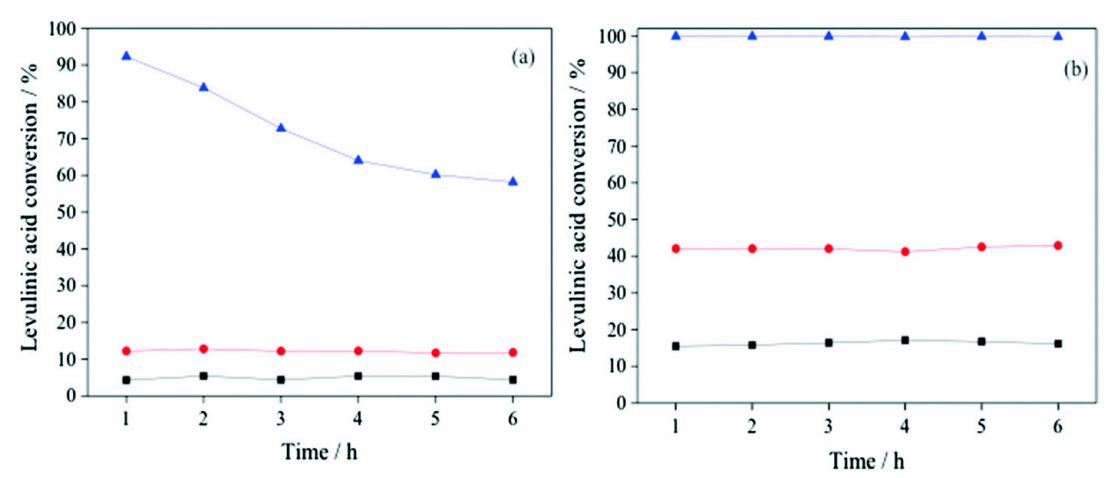

Figure 7. Levulinic acid conversion versus time over $\mathrm{Mo}_{2} \mathrm{C} / \mathrm{AC}(\mathbf{a})$ and $\mathrm{Mo}_{2} \mathrm{C} / \mathrm{CNT}(\mathbf{b})$ at 30 bar of $\mathrm{H}_{2}$ and LSHV $=3 \mathrm{~h}^{-1}$. Tests performed at $100{ }^{\circ} \mathrm{C}(\boldsymbol{\square}), 150{ }^{\circ} \mathrm{C}(\bullet)$ and $200{ }^{\circ} \mathrm{C}(\boldsymbol{\Delta})$. Reproduced with permission from [30]. Copyright The Royal Society of Chemistry, 2014. 
To better highlight the potential of $\mathrm{Mo}_{2} \mathrm{C}$ as an alternative to the noble metal-based catalysts, the authors performed the same reaction on a prepared $5 \mathrm{wt} \%$ Ru catalyst supported on AC (figure not shown). At $150{ }^{\circ} \mathrm{C}, 83 \%$ LA conversion was obtained versus a full conversion at $200{ }^{\circ} \mathrm{C}$. The Ru/AC catalyst is therefore more active than $\mathrm{Mo}_{2} \mathrm{C} / \mathrm{CNT}$ at $150{ }^{\circ} \mathrm{C}$ ( $83 \%$ versus $42 \%$ respectively) and similar results were obtained at $200{ }^{\circ} \mathrm{C}$. $\mathrm{CO}$ chemisorption studies at $100{ }^{\circ} \mathrm{C}$ and $150{ }^{\circ} \mathrm{C}$ were carried out in order to better compare both catalysts. The number of metal active sites deriving from the $\mathrm{CO}$ chemisorption allows the calculation of the turnover frequency (TOF). At $150{ }^{\circ} \mathrm{C}$, the TOF obtained for the LA hydrogenation to GVL were $10.3 \mathrm{~h}^{-1}, 4.5 \mathrm{~h}^{-1}$ and $2.3 \mathrm{~h}^{-1}$ for $20 \% \mathrm{Mo}_{2} \mathrm{C} / \mathrm{CNT}, 20 \% \mathrm{Mo}_{2} \mathrm{C} / \mathrm{AC}$ and $5 \% \mathrm{Ru} / \mathrm{AC}$, respectively. $20 \% \mathrm{Mo}_{2} \mathrm{C} / \mathrm{CNT}$ exhibits a higher TOF than $5 \% \mathrm{Ru} / \mathrm{AC}$.

Unsupported $\mathrm{Mo}_{2} \mathrm{C}$ was either prepared by the physical mixture of molybdenum oxide, $\mathrm{MoO}_{3}$, and CNTs or by using nanostructured $\alpha-\mathrm{MoO}_{3}$ as a precursor. The catalysts obtained after carburization were labeled $\mathrm{Mo}_{2} \mathrm{C} \_\mathrm{PM}$ and $\mathrm{Mo}_{2} \mathrm{C} \_\mathrm{N}$, respectively. They were further tested, together with commercial $\mathrm{MoO}_{3}$, during aqueous phase LA hydrogenation. All catalysts were active. After $6 \mathrm{~h}$ reaction, $20 \%, 45 \%$ and $60 \%$ LA conversion was obtained for $\mathrm{Mo}_{2} \mathrm{C}_{-} \mathrm{PM}, \mathrm{Mo}_{2} \mathrm{C}_{-} \mathrm{C}$ and $\mathrm{Mo}_{2} \mathrm{C} \_\mathrm{N}$, respectively [35]. For a better understanding of the catalytic performance, $\mathrm{CO}$ chemisorption was carried out. The nature of the active sites is similar in both synthesized catalysts, but the preparation method influenced the total number of sites. Despite a higher surface area, $\mathrm{Mo}_{2} \mathrm{C} \_\mathrm{PM}$ presented a lower $\mathrm{CO}$ uptake and catalytic activity compared to the nanostructured $\mathrm{Mo}_{2} \mathrm{C}_{-} \mathrm{N}$. On $\mathrm{Mo}_{2} \mathrm{C}_{-} \mathrm{PM}$, agglomeration of well-orientated $\beta-\mathrm{Mo}_{2} \mathrm{C}$ nanoparticles implies a higher surface area, as well as a coating of particles by a thin layer of carbon [50,51]. The results of this research underlined the importance of the control over the particle morphology and size, compared to the surface area in unsupported molybdenum carbide for LA hydrogenation.

From both examples, molybdenum carbide, unsupported or supported, can be a valid candidate for replacing noble metal-based catalysts in the hydrogenation of LA.

Sustainable production of chemicals. Ethylene glycol (EG), is the monomer for the large-scale manufacture of poly(ethylene teraphtalate) (PET) fibers and bottles [52]. Ji et al. reported on the catalytic conversion of cellulose to EG over supported carbide catalysts [53]. The reaction was carried out over $2.5 \% \mathrm{Pt} / \mathrm{AC}, \mathrm{W}_{2} \mathrm{C} / \mathrm{AC}-800$ (30 wt \% tungsten nominal value) and $\mathrm{Mo}_{2} \mathrm{C} / \mathrm{AC}-700$ (30 wt \% molybdenum nominal value). $\mathrm{W}_{2} \mathrm{C} / \mathrm{AC}-800$ and $\mathrm{Mo}_{2} \mathrm{C} / \mathrm{AC}-700$ are active carbon tungsten carbide catalyst carburized at $800^{\circ} \mathrm{C}$ and molybdenum carbide supported on active carbon carburized at $700{ }^{\circ} \mathrm{C}$, respectively. The difference in the carburization temperature depends upon the temperature at which the corresponding pure phase is reached. The catalytic transformation of cellulose was performed at $245{ }^{\circ} \mathrm{C}$, at an initial $\mathrm{H}_{2}$ pressure of $6 \mathrm{MPa}$ for $0.5 \mathrm{~h}$. The catalysts were active, $98 \%$ and $85 \%$ cellulose conversion was obtained for $\mathrm{W}_{2} \mathrm{C} / \mathrm{AC}-800$ and $\mathrm{Mo}_{2} \mathrm{C} / \mathrm{AC}-700$, respectively. The cellulose conversion was calculated via the cellulose weight difference before and after reaction. $\mathrm{Pt} / \mathrm{AC}$ was less active $(66 \%)$ than the carbide catalysts. $27.4 \%, 8.2 \%$ and 5.3\% EG yield was obtained for $\mathrm{W}_{2} \mathrm{C} / \mathrm{AC}-800, \mathrm{Pt} / \mathrm{AC}$ and $\mathrm{Mo}_{2} \mathrm{C} / \mathrm{AC}-700$, respectively. A low EG yield was obtained over $\mathrm{Mo}_{2} \mathrm{C} / \mathrm{AC}-700$, which formed more unsaturated acids, due to an incomplete hydrolysis of cellulose. The high selectivity to EG, instead of sorbitol, demonstrates that the reaction involves not only the hydrolysis of cellulose to glucose and the hydrogenation of glucose to sorbose, but also the cleavage of the C-C bonds. To highlight the effect of the metal active phase and the support itself, the authors moved to alumina as the support. Tungsten carbide or molybdenum carbide supported catalysts were poorly selective to polyols. Mesoporous carbon $(\mathrm{MC})$ was also used as a support to disperse tungsten carbide $\left(\mathrm{WC}_{\mathrm{x}}\right)$ by Zhang et al. and $73 \%$ EG yield was reached [54]. MC might facilitate the hydrogenation activity of the unsaturated intermediates formed during the conversion of cellulose to EG. Dispersion and accessibility of active components of $\mathrm{WC}_{\mathrm{x}}$ could be favored by the $3 \mathrm{D}$ interconnected mesoporous structure.

Hot water and the tungsten oxide surface might provide the acid sites necessary for cellulose hydrolysis [55], while the platinum-like electronic properties of tungsten carbide deliver the hydrogenation sites [18]. Moreover, hot water helps in the dissolution of cellulose. Once improved 
dissolution and hydrolysis of cellulose are carried out, the subsequent hydrogenolysis reaction to produce EG becomes easier.

\subsubsection{Hemicellulose}

The effective use of biomass is also directly associated with the transformation of sugars (xylose) within hemicellulose, into more valuable products (furfural, furfuryl alcohol, methylfuran, etc.). $\mathrm{Mo}_{2} \mathrm{C}$, which was demonstrated as active in the cellulose transformation, is also reported to be a highly selective catalyst in the HDO of furfural. Furfural, a $\mathrm{C}_{5} \mathrm{H}_{4} \mathrm{O}_{2}$ molecule, is an important intermediate for the formation of important fine chemicals, such as 2-methylfuran, furfuryl alcohol and tetrahydrofurfuryl alcohol or the corresponding ethers, such as isopropryl furfuryl ether (1) and isopropryl tetrahydrofurfuryl ether (2), when isopropanol is used as the solvent (Figure 8). A $60 \%$ selectivity of 2-methylfuran results from the furfural $\mathrm{HDO}$ at $150{ }^{\circ} \mathrm{C}$ in a flow reactor [56]. 2-methylfuran, which has a high research octane number (RON 131) and a high energy density, together with low water solubility, is considered a promising biofuel $[57,58]$.

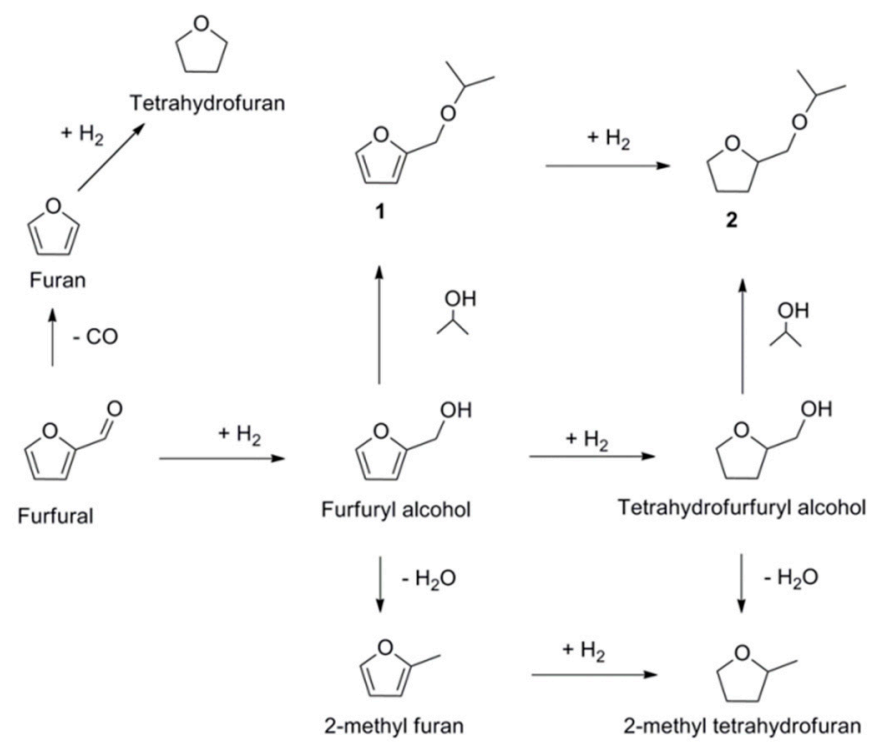

Figure 8. Schematic representation of reaction pathways during furfural hydrogenation using isopropanol as solvent.

Through a combined approach of density function theory (DFT) and ultra-high vacuum (UHV) studies on model surfaces, Xiong and coauthors investigated on the $\mathrm{HDO}$ of furfural on $\mathrm{Mo}_{2} \mathrm{C}$ [56]. The DFT calculations showed a strong interaction between the $\mathrm{C}=\mathrm{O}$ (aldehyde) bond of furfural and the $\mathrm{Mo}_{2} \mathrm{C}(001)$ surface. For comparison, they also studied the interaction between $\mathrm{Pt}(111)$ and $\mathrm{Mo}_{2} \mathrm{C}$. The $\mathrm{Mo}_{2} \mathrm{C}$ surface, compared to $\mathrm{Pt}(111)$, exhibited stronger affinity to the $\mathrm{C}=\mathrm{O}$ (aldehyde) bond. This strong interaction was confirmed by high-resolution electron energy loss spectroscopy (HREELS) experiments on model $\mathrm{Mo}_{2} \mathrm{C}$ surfaces prepared on a $\mathrm{Mo}(110)$ single crystal. Surface experiments in UHV of furfural and furfuryl alcohol suggest that $\mathrm{Mo}_{2} \mathrm{C}$ could selectively cleave the $\mathrm{C}=\mathrm{O}$ (aldehyde) bond of furfural to produce 2-methylfuran as the main product. The HREELS of furfuryl alcohol and 2-methylfuran on $\mathrm{Mo}_{2} \mathrm{C}$ are compared (Figure 9) in order to identify possible reaction intermediates during the $\mathrm{HDO}$ of furfural. At $27^{\circ} \mathrm{C}$, a methylfuran-like intermediate was observed for both furfural and furfuryl alcohol reaction on $\mathrm{Mo}_{2} \mathrm{C}$ at $27^{\circ} \mathrm{C}$ and $-23^{\circ} \mathrm{C}$, respectively. 


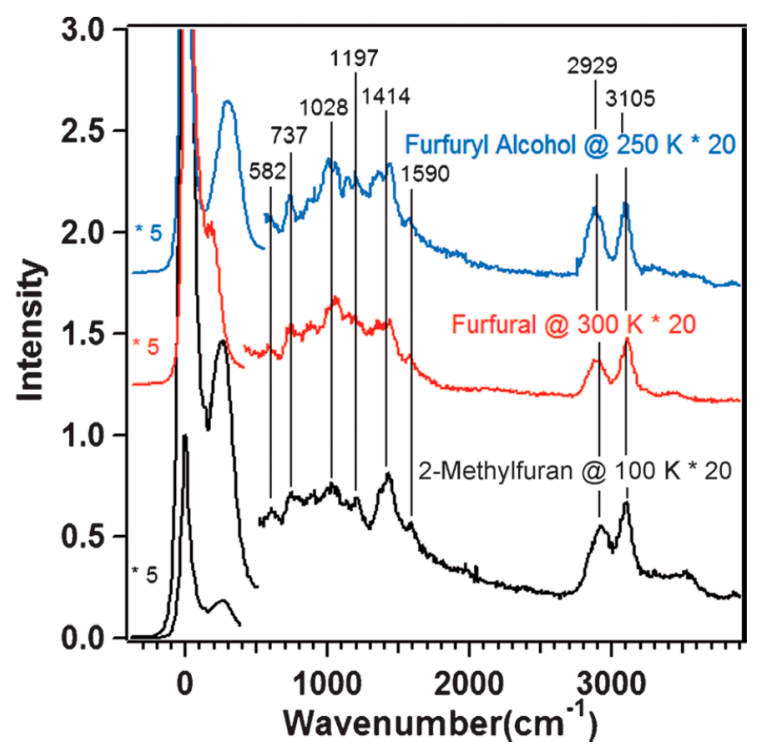

Figure 9. HREELS of furfural (red), and 2-methylfuran (black) and furfuryl alcohol (blue) adsorbed onto $\mathrm{Mo}_{2} \mathrm{C}$ after annealing the surface to various temperatures. Adapted with permission from [56]. Copyright WILEY-VCH Verlag GmbH and Co. KGaA, Weinheim, 2014.

McManus and Vohs used a model catalyst that consisted of a $\mathrm{Mo}_{2} \mathrm{C}$ thin film on a $\mathrm{Mo}(100)$ single crystal for the deoxygenation of glycolaldehyde and furfural [59]. Deoxygenation products were detected by temperature-programmed desorption (TPD). Indeed, ethanol and ethylene were detected in the case of glycolaldehyde, and methylfuran in the case of furfural. For a better insight into the bonding configuration, the authors performed HREELS in order to identify any stable reaction intermediates. The authors concluded that both molecules interact with the $\mathrm{Mo}_{2} \mathrm{C} / \mathrm{Mo}(100)$ surface through both carbon and oxygen atoms, i.e., the aldehyde functional group. Moreover, $\mathrm{Mo}_{2} \mathrm{C} / \mathrm{Mo}(100)$ is active in the production of 2-methylfuran, but inactive in the hydrogenation of the furan ring, since tetrahydromethylfuran and tetrahydrofurfuryl alcohol were not produced.

The ability of the $\mathrm{Mo}_{2} \mathrm{C}$ surface to selectively deoxygenate was also investigated by Xiong et al. with furfural and furfuryl alcohol [60]. They were able to form 2-methylfuran through a 2-methylfuran-like intermediate from both substrates. Investigations on both substrates contribute to a better understanding of the impact of the furan ring on the reaction pathways. Indeed, together with the production of 2-methylfuran, a reforming reaction, as well as the complete decomposition of the furfural, could occur. In the case of furfural, 2-methylfuran (selectivity 38\%) was detected by TPD between $7{ }^{\circ} \mathrm{C}$ and $127^{\circ} \mathrm{C}$. This suggests that $\mathrm{Mo}_{2} \mathrm{C}$ could selectively cleave the $\mathrm{C}=\mathrm{O}$ (aldehyde) of furfural, while not affecting the furan ring. The simultaneous detection of $\mathrm{H}_{2}$ and $\mathrm{CO}$ at $44{ }^{\circ} \mathrm{C}$, together with carbon accumulation, revealed an additional reforming reaction (17\% selectivity) pathway. The complete decomposition ( $45 \%$ selectivity) pathway was suggested by the detection of extra surface oxygen by Auger Electron Spectroscopy.

In the case of furfuryl alcohol conversion over $\mathrm{Mo}_{2} \mathrm{C}$, 2-methylfuran was mainly detected between $-33^{\circ} \mathrm{C}$ and $127^{\circ} \mathrm{C}$, hinting at a selective deoxygenation of furfuryl alcohol on the C-O (alcohol). However, together with the deoxygenation, neither hydrogenation of furfural nor dehydrogenation of furfuryl alcohol were observed in TPD and HREELS. For the same range of temperatures, the authors concluded that hydrogenation-dehydrogenation reactions of the two substrates would not interfere with the deoxygenation reaction. This is in agreement with Medlin et al. who reported that the furan ring weakened the C-O bond of the furfuryl alcohol [61].

Performing kinetic measurements of vapor-phase furfural $\mathrm{HDO}$ over a $\mathrm{Mo}_{2} \mathrm{C}$ catalyst, Lee and coauthors [32] converted furfural to 2-methylfuran with 50-60\% selectivity, $\mathrm{C}_{10}{ }^{+}$products (such as decane and 2-(furan-2-ylmethyl)-5-methylfuran) and furfuryl alcohol at $150{ }^{\circ} \mathrm{C}$. Selective $\mathrm{C}=\mathrm{O}$ 
bond cleavage, instead of C-C bond cleavage, was suggested by the low amount of furan $(<1 \%)$ produced. Moreover, consecutive hydrogenation of 2-methylfuran did not occur, as established by the absence of 2-methyltetrahydrofuran, indicating an efficient hydrogen usage during the reaction. Gas chromatography mass spectroscopy analysis of the reactor effluents confirmed that not only 2-methylfuran was produced during the $\mathrm{HDO}$ of furfural, but also $\mathrm{C}_{10}{ }^{+}$products $(\sim 30 \%)$. The authors inferred that the $\mathrm{C}_{10}{ }^{+}$products result from the dimerization of furfural and/or furfuryl alcohol through acid-catalyzed reactions [62,63]. Probe reaction studies, as well as $\mathrm{NH}_{3}$ TPD experiments performed by Bej et al. highlighted the existence of acidic sites on $\mathrm{Mo}_{2} \mathrm{C}$ catalysts [64]. The $\mathrm{Mo}_{2} \mathrm{C}$ catalyst suffers, however, from deactivation, mainly due to a loss of active sites (CO chemisorption analysis), which is a consequence of carbonaceous species deposition on the surface of the catalyst. This is confirmed by High resolution transmission electron microscopy (HRTEM) images. Furfural conversion, as well as product selectivity, were reestablished under $\mathrm{H}_{2}$ flow at $477^{\circ} \mathrm{C}$ for one hour after two regeneration cycles (Figure 10).

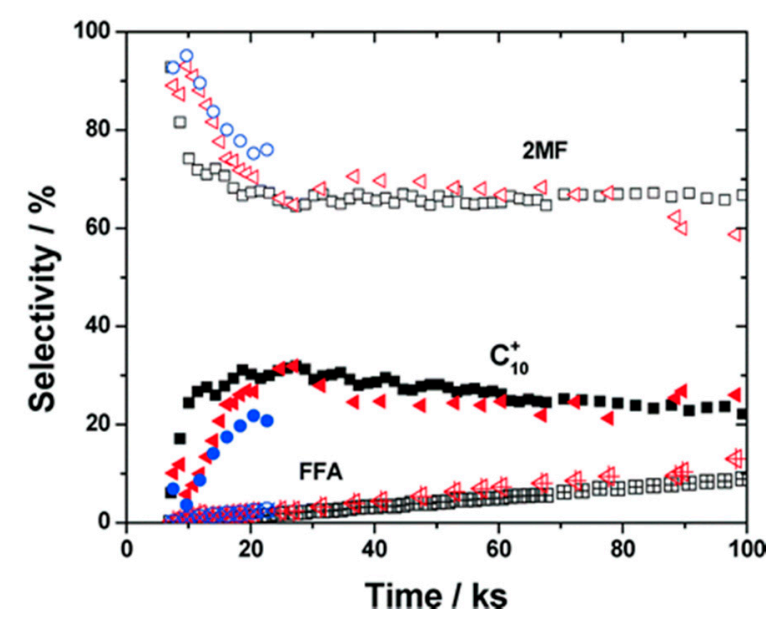

Figure 10. Furfural hydrodeoxygenation product selectivity as a function of time on $\mathrm{Mo}_{2} \mathrm{C}$ catalysts: 2-methylfuran (2MF), $\mathrm{C}_{10}{ }^{+}$, and furfuryl alcohol (FFA). Fresh $\mathrm{Mo}_{2} \mathrm{C}$ catalyst $(\square, \boldsymbol{\square}, \boxplus$ ) and the same catalyst after the first $(\triangleleft, 4, \sharp)$ and second $(\odot, \bullet, \cdots)$ regeneration cycle. Reproduced with permission from [32]. Copyright The Royal Society of Chemistry, 2014.

Based on DFT calculations with a correction for the long-range dispersion interaction (PBE-D3), Shi et al. also studied the furfural conversion to 2-methylfuran and furan on the clean and $4 \mathrm{H}$ pre-covered $\mathrm{Mo}_{2} \mathrm{C}(101)$ surfaces [65]. The $\mathrm{Mo}_{2} \mathrm{C}(101)$ surface has two distinct surface sites, the unsaturated $\mathrm{C}_{\mathrm{A}}$ atoms for $\mathrm{H}$ adsorption and unsaturated $\mathrm{Mo}_{\mathrm{A}}$ atoms for furfural adsorption. $\mathrm{C}_{\mathrm{A}}$ represents the 4-coordinated (two surface Mo atoms and two bulky phase Mo atoms) $\mathrm{C}$ atom; while $\mathrm{Mo}_{\mathrm{A}}$ stands for 10-coordinated (three surface Mo atoms, three surface $C$ atoms and four bulky phase Mo atoms) surface Mo. The adsorption energy value of furfural at the $\mathrm{Mo}_{\mathrm{A}}$ compared to those of $\mathrm{H}$ at the $\mathrm{Mo}_{\mathrm{A}}$ and $C_{A}$ sites indicates that the surface will be principally covered by furfural. From their study, furfural is converted according to two parallel and competitive reaction paths. The first one leads to the formation of 2-methylfuran through first the furfural hydrogenation into furfuryl oxide, followed by the dissociation of the later into furfuryl and finally the formation of 2-methylfuran. The second reaction path, on the clean surface, results in the formation of furan after the $\mathrm{C}-\mathrm{H}$ dissociation of furfural. In this case, the furfural dissociation is favored in comparison to the furfural hydrogenation to furfuryl oxide. According to their calculations, the authors recommend to first pretreat the catalyst with $\mathrm{H}_{2}$ before carrying out the furfural hydrogenation. 


\subsubsection{Lignin}

Lignin is an important component of lignocellulosic biomass after harvest [66] and its composition varies according to the biomass source. Kraft lignin is waste produced during the utilization of lignocellulosic biomass in paper production [67]. Lignin is a complex and irregular macromolecule, constituting of mainly hydroxyphenyl propane and aliphatic chains [5,68]. Lignin has a lower oxygen content than that of polysaccharides and is thus a promising candidate to produce renewable petroleum-derived products.

Vapor phase hydrodeoxygenation of a lignin-derived phenolic compound mixture to aromatics over a $\mathrm{Mo}_{2} \mathrm{C}$ catalyst was investigated by Chen et al. [69]. The authors carried out the vapor phase HDO of a mixture of phenolic compounds such as m-cresol, anisole, 1,2-dimetoxybenzene (DMB) and guaiacol (GUA) over a $\mathrm{Mo}_{2} \mathrm{C}$ catalyst at $260-280{ }^{\circ} \mathrm{C}$ and at ambient pressure. The x-ray diffraction pattern identified $\beta-\mathrm{Mo}_{2} \mathrm{C}$ as the major carbide phase. At $280{ }^{\circ} \mathrm{C}, 95 \%$ conversion was observed with a $95 \%$ yield of benzene and toluene, the deoxygenate aromatics. The successive hydrogenation reaction of the HDO products to cyclohexane and methylcyclohexane were limited to less than $10 \%$ selectivity (molar basis) at $280^{\circ} \mathrm{C}$ with a high hydrogen to oxygenate molar ratio ( 3300). The authors further investigated the in situ titration of a mixture of toluene and benzene over $\mathrm{Mo}_{2} \mathrm{C}$ in the presence of methanol or water at $80^{\circ} \mathrm{C}$. The hydrogenation of the aromatic rings was inhibited. The results suggest that the introduction of the oxygen-containing compounds that constitute lignin to $\mathrm{Mo}_{2} \mathrm{C}$ under HDO reaction modifies the surface catalyst and therefore impedes the hydrogenation property of the molybdenum carbide catalyst.

Ma et al. reported on the transformation of Kraft lignin into valuable chemicals over a molybdenum carbide catalyst in supercritical ethanol [67]. The products of reaction were a mixture of aliphatic alcohols, esters, monophenols, benzyl alcohols and arenes, with ester the predominant product (yield of $947 \mathrm{mg} / \mathrm{g}$ of lignin).

Kraft lignin was also converted by Ma and coauthors into $\mathrm{C}_{6}-\mathrm{C}_{10}$ chemicals at high-yield without any tar or char formation over a nanostructured $\alpha$-molybdenum carbide catalyst [33]. Ethanolysis of the Kraft lignin in supercritical ethanol without the addition of gaseous hydrogen took place over an activated carbon-supported $\alpha$-molybdenum carbide $\left(\alpha-\mathrm{MoC}_{1-x} / \mathrm{AC}\right)$ catalyst. At the end of the reaction, aliphatic compounds in $\mathrm{C}_{6}$ alcohols and $\mathrm{C}_{8}-\mathrm{C}_{10}$ esters, as well as aromatic compounds in the form of $\mathrm{C}_{8}-\mathrm{C}_{10}$ arenes, phenols and benzyl alcohols were produced. 25 products were identified and quantified and their overall total yield was $1.64 \mathrm{~g}$ per gram of lignin; almost 15 times more than the yield obtained with noble metal-based catalysts [70]. Due to the fact that the obtained yield is over $100 \%$, it can be assumed that ethanol participates in the reaction. Indeed, the solvent here and the catalyst are both protagonists and play a role in the molecular yields and product composition.

Hydrodeoxygenation of guaiacol, a widely used product model resulting from lignin depolymerization, was performed on molybdenum carbide supported on carbon catalysts. Understanding the influence of the carbon support on the Mo phase justified the choice of activated carbon, multi-walled carbon nanotubes and carbon nanofibers. The supports were impregnated either with ammonium molybdate labeled Am or molybdic acid labeled Ac, and had varying loading (7.5 wt \% or $20 \mathrm{wt} \%)$. On activated carbon, an amorphous Mo phase was obtained while on CNT, large $\mathrm{Mo}_{2} \mathrm{C}$ or $\mathrm{MoC}$ particles $(\sim 2 \mu \mathrm{m})$ were revealed in TEM images. The Carbon Nanofibers (CNF)-supported catalysts contained molybdenum carbide in nanoparticle form. The authors based their study on the yield of phenol obtained after the $\mathrm{HDO}$ of guaiacol in dodecane as the solvent at $300{ }^{\circ} \mathrm{C}$. The catalysts, $20 \% \mathrm{Ac} / \mathrm{CNF}, 7.5 \% \mathrm{Am} / \mathrm{CNF}, 20 \% \mathrm{Am} / \mathrm{CNF}$ and $20 \% \mathrm{Am} / \mathrm{CNT}$, which showed relevant yield $(\sim 35 \%)$ to phenol, all contained crystalline $\mathrm{Mo}_{2} \mathrm{C}$. By increasing the reaction temperature to $350{ }^{\circ} \mathrm{C}$, almost $98 \%$ guaiacol conversion and about $50 \%$ selectivity to phenol were reported, suggesting that the crystalline $\mathrm{Mo}_{2} \mathrm{C}$ is selective to phenol. The durability of $20 \% \mathrm{Am} / \mathrm{CNF}$ was tested at $300{ }^{\circ} \mathrm{C}$ : over three runs, the conversion to guaiacol and the yield to phenol decreased, mainly due to coke formation. However, the authors emphasized that both the guaiacol and the amount of coke decrease continuously. This result hints that not only coke formation is responsible 
for the observed deactivation, but also probably the encapsulation of carbide particles into the carbon support, as suggested by Jongerius et al. [37].

Altering the carbon support to hollow carbon spheres (HCS), Engelhardt and coauthors studied the $\mathrm{HDO}$ of phenol over $\mathrm{Mo}_{2} \mathrm{C}$ and more specifically the direct deoxygenation (DDO) and the hydrogenation (HYD), the two mechanisms of HDO (Figure 11) [71].

\section{Direct Deoxygenation Route}

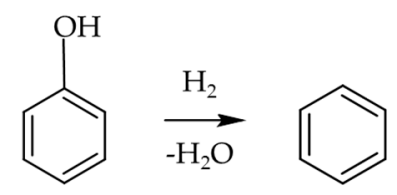

Hydrogenation Route

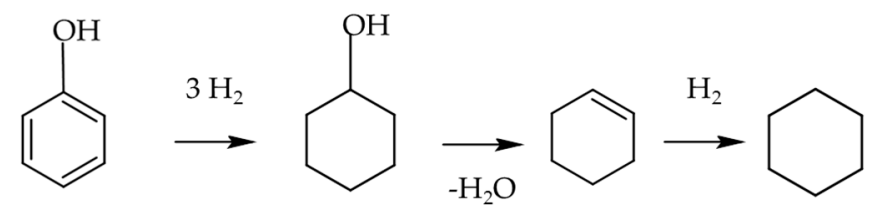

Figure 11. Proposed HDO pathways for phenol reported by Engelhardt.

In the phenol DDO on $\mathrm{MoC}_{\mathrm{x}} / \mathrm{HCS}$, the authors reported a preferred pathway in the DDO both from experimental and computational investigations. A high selectivity to benzene (85\%) was obtained at $350{ }^{\circ} \mathrm{C}$. They explained this predilection to direct deoxygenation by the affinity of phenol to adsorb on the hydrogenated $\mathrm{Mo}_{2} \mathrm{C}$ surface. The negative effect of water during the phenol HDO was also examined. Both molecules, phenol and water, are in competition for the Mo adsorption sites. When the water partial pressure increases, the Mo active sites are covered by water, thus obstructing the access of phenol to the Mo surface atoms. However, the effect is reversible. Deactivation of the catalyst is therefore due to, first, the competition between water and phenol and, second, to the irreversible formation of $\mathrm{MoO}_{2}$.

Due to its similar catalytic properties compared to Pt-group metals in diverse reactions, including hydrogenation, tungsten carbide was utilized as a catalyst for the transformation of lignin [72,73]. The C-O bond cleavage of a model compound of lignin, 2-(2-Methoxyphenoxy)-1-phenylethanol a common $\beta-\mathrm{O}-4$ dimeric model, on $\mathrm{W}_{2} \mathrm{C} / \mathrm{AC}$ was investigated [72]. The authors investigated the effect of the reaction temperature and solvent on the activity and selectivity. 2-(2-Methoxyphenoxy)1-phenylethanol converts to mainly guaiacol, followed randomly by styrene and ethylbenzene. At $200{ }^{\circ} \mathrm{C}$, low conversion $(23.3 \%)$ and low selectivity to the products of reaction were reported, with an almost similar selectivity to styrene $(16 \%)$ and guaiacol $(17.4 \%)$. At $260{ }^{\circ} \mathrm{C}$ the initial substrate was practically fully converted after $2 \mathrm{~h}$ with ethylbenzene and guaiacol yields of $88.4 \%$ and $93.0 \%$, respectively. $\mathrm{W}_{2} \mathrm{C} / \mathrm{AC}$ is thus a promising catalyst for the cleavage of $\beta-\mathrm{O}-4$, without altering the aromatic rings of the lignin compounds. The study was extended to other molecules and $\mathrm{W}_{2} \mathrm{C} / \mathrm{AC}$ was active in destroying more resistant linkages in lignin, namely $\alpha-\mathrm{O}-4$ and $\beta-\beta$. It is worth mentioning, that at higher reaction temperature, the selectivity to ethylbenzene (88.4\%) is higher than the selectivity of styrene (8.5\%). At lower temperature, the selectivity to ethylbenzene was $2.3 \%$ and the selectivity of styrene was $16.0 \%$. At higher reaction temperature, hydrogenation of the alkene group into styrene is favored. Reaction in methanol is preferable, as the solvent allows the in situ hydrogen-transfer reaction from methanol to the substrate on $\mathrm{W}_{2} \mathrm{C} / \mathrm{AC}$. The catalyst was not only active and selective, but also stable along five runs with a nearly comparable aptitude in the $\mathrm{C}-\mathrm{O}$ bond cleavage.

Moving away from the model compound, Guo and coworkers studied the transformation of corn stalk lignin over $\mathrm{W}_{2} \mathrm{C} / \mathrm{AC}$ in methanol [73]. The lignin was extracted by three different 
methods, namely organosolv, alkaline and klason. $\mathrm{W}_{2} \mathrm{C} / \mathrm{AC}$ is a potential active catalyst for the hydrocracking of various lignins into aromatics. The high selectivity of the catalyst to aryl ether bonds was established by the high yield in aromatic liquid oil and the absence of cycloalkane. The three different extraction techniques lead to the formation of lignins with different structures and linkage strength. Organosolv lignin was easily depolymerized by $\mathrm{W}_{2} \mathrm{C} / \mathrm{C}$ and a high-yield in oil was obtained, while klason and alkaline lignins with resistant structure were difficult to fragment. Dividing organosolv lignin category to hardwood (basswood and poplar) and softwood (pine and spruce), the study described that softwood lignin is more difficult to hydrocrack compared to its hardwood counterpart. The results can be explained by the higher molecular weights and the presence of more resistant $\beta-5$ linkages contained in softwood lignin. Moreover, the catalytic conversion of these lignins is also correlated to both the internal mass transportation and the surface chemistry.

\subsubsection{Reforming Reactions: Selective C-C Bond Scission}

In contrast to the HDO reaction, where $\mathrm{C}-\mathrm{O}$ cleavage is desired, in the reforming reaction the $\mathrm{C}-\mathrm{O}$ bond should be maintained, while $\mathrm{C}-\mathrm{C}$ bond is cleaved. The interest in selective reforming of oxygenates lies in the possibility of producing hydrogen or syngas, which are necessary for several applications. Tar, a byproduct of biomass gasification, which leads to the formation of hydrogen and synthesis gas, is undesired [74]. Tar condenses at reduced temperature, thus blocking and fouling process equipment, such as engines and turbines. Hydrogen finds many applications as an energy carrier, for example in fuel cells for power generation.

$\mathrm{Mo}_{2} \mathrm{C}$ supported biomass char $\left(\mathrm{Mo}_{2} \mathrm{C} / \mathrm{BC}\right)$ was utilized as a catalyst for the steam-reforming of heavy tar into hydrogen between 550 and $750{ }^{\circ} \mathrm{C}$ [75]. In order to obtain $\mathrm{H}_{2}$ and $\mathrm{CO}_{2}$, the authors proposed that the biomass tar is first decomposed to $\mathrm{H}_{2}$ and $\mathrm{CO}$ on the catalyst. The resulting $\mathrm{CO}$ reacts further with the excess steam through water gas shift reaction, leading finally to the formation of the desired $\mathrm{H}_{2}$ and $\mathrm{CO}_{2}$.

High yields were observed with an optimized Mo loading of $20 \mathrm{wt} \%$ at a reaction temperature of $650{ }^{\circ} \mathrm{C}$. At higher temperatures, $\mathrm{Mo}_{2} \mathrm{C}$ is oxidized to $\mathrm{MoO}_{2}$, as reported previously by Darujati et al. [76] . $\mathrm{MoO}_{2}$, known not to be active in the steam reforming reaction, was identified in the XRD pattern of the spent catalyst at the expense of the $\mathrm{Mo}_{2} \mathrm{C}$ phase. Carburization at $900{ }^{\circ} \mathrm{C}$ allows the full recovery of the $\mathrm{Mo}_{2} \mathrm{C}$ phase.

\section{Conclusions and Perspective}

Transition metal carbides have been shown to be good candidates to substitute noble metal-based catalysts for biomass transformation. Their metal-acid bifunctionality makes them effective catalysts for the hydrogenolysis, hydrogenation and isomerization of biomass-based feedstock to fuels and chemicals. Metal carbides exhibit similar catalytic performance to those of Pt-group metals, but present a lower cost. For example, $\mathrm{W}_{2} \mathrm{C}$ has attracted much interest, because it exhibits high catalytic performance in a variety of reactions, such as hydrogenation and hydrodeoxygenation of cellulose, hemicellulose and lignin derived molecules. Another example is $\mathrm{W}_{2} \mathrm{C} / \mathrm{AC}$, which is highly active and selective in the cleavage of aryl C-O bonds in lignin, breaking the $\beta-\mathrm{O}-4$ bond as well as the $\alpha-\mathrm{O}-4$ and $\beta-\beta$ linkages, which are the more resistant ones. Moreover, the $\mathrm{C}-\mathrm{O}$ bond cleavage aptitude, important in the HDO of lignin, was kept constant for up to 5 cycles.

A drawback of these catalytic systems is deactivation, which has been often observed in the liquid phase reaction, due to coke deposition and leaching, but also due to the over-reduction of the carbide to the metallic form. It has been shown that one strategy to enhance the metal carbides' stability is to deposit them on the external surface of a support, such as on activated carbon or carbon nanotubes. However, a strong interaction between the metal carbides and the support is never observed, and the deactivation due to leaching of the active phase is still an issue that needs to be solved. A possible solution to overcome the low durability of these systems is the incorporation of finely dispersed carbide nanoparticles into, rather than onto, the porous supports, such as CNTs or 
mesoporous carbon. This incorporation not only allows a much better control of the particle size during the synthesis, but also provides a further stabilization of these carbides during the reaction. Moreover, several attempts in promoting theses carbides with $\mathrm{Ni}$ or $\mathrm{Co}$. are reported, but more efforts should be dedicated to improving the activity over a longer time and the selectivity to the desired products of reaction. Trusting that the properties of transition metal carbides can soon be improved, it can be confidently stated that these environmentally green catalysts represent an efficient step forward in the challenge of the cost-efficient production of aromatic chemicals from biomass.

Author Contributions: Carine E. Chan-Thaw and Alberto Villa wrote the paper.

Conflicts of Interest: The authors declare no conflict of interest.

\section{References}

1. Navarro, R.M.; Peña, M.A.; Fierro, J.L.G. Hydrogen production reactions from carbon feedstocks: Fossil fuels and biomass. Chem. Rev. 2007, 107, 3952-3991. [CrossRef] [PubMed]

2. Corma Canos, A.; Iborra, S.; Velty, A. Chemical routes for the transformation of biomass into chemicals. Chem. Rev. 2007, 107, 2411-2502. [CrossRef] [PubMed]

3. Okkerse, C.; van Bekkum, H. From fossil to green. Green Chem. 1999, 1, 107-114. [CrossRef]

4. Huber, G.W.; Shabaker, J.W.; Dumesic, J.A.; Dumesic, J.A. Raney Ni-Sn Catalyst for H2 Production from Biomass-Derived Hydrocarbons. Science 2003, 300, 2075-2077. [CrossRef] [PubMed]

5. Huber, G.W.; Iborra, S.; Corma, A. Synthesis of transportation fuels from biomass: Chemistry, catalysts, and engineering. Chem. Rev. 2006, 106, 4044-4098. [CrossRef] [PubMed]

6. Gallezot, P. Conversion of biomass to selected chemical products. Chem. Soc. Rev. 2012, 41, 1538-1558. [CrossRef] [PubMed]

7. Chheda, J.N.; Huber, G.W.; Dumesic, J.A. Liquid-Phase Catalytic Processing of Biomass-Derived Oxygenated Hydrocarbons to Fuels and Chemicals. Angew. Chem. Int. Ed. 2007, 46, 7164-7183. [CrossRef] [PubMed]

8. De, S.; Dutta, S.; Saha, B. Critical design of heterogeneous catalysts for biomass valorization: Current thrust and emerging prospects. Catal. Sci. Technol. 2016, 6, 7364-7385. [CrossRef]

9. Furimsky, E. Catalytic hydrodeoxygenation. Appl. Catal. A Gen. 2000, 199, 147-190. [CrossRef]

10. Zhao, C.; Kou, Y.; Lemonidou, A.A.; Li, X.; Lercher, J.A. Highly Selective Catalytic Conversion of Phenolic Bio-Oil to Alkanes. Angew. Chem. Int. Ed. 2009, 48, 3987-3990. [CrossRef] [PubMed]

11. Saidi, M.; Samimi, F.; Karimipourfard, D.; Nimmanwudipong, T.; Gates, B.C.; Rahimpour, M.R. Upgrading of lignin-derived bio-oils by catalytic hydrodeoxygenation. Energy Environ. Sci. 2014, 7, 103-129. [CrossRef]

12. Serrano-Ruiz, J.C.; West, R.M.; Dumesic, J.A. Catalytic Conversion of Renewable Biomass Resources to Fuels and Chemicals. Annu. Rev. Chem. Biomol. Eng. 2010, 1, 79-100. [CrossRef] [PubMed]

13. Jae, J.; Zheng, W.; Karim, A.M.; Guo, W.; Lobo, R.F.; Vlachos, D.G. The Role of Ru and $\mathrm{RuO}_{2}$ in the Catalytic Transfer Hydrogenation of 5-Hydroxymethylfurfural for the Production of 2,5-Dimethylfuran. ChemCatChem 2014, 6, 848-856. [CrossRef]

14. Gordon, R.B.; Bertram, M.; Graedel, T.E. Metal stocks and sustainability. Proc. Natl. Acad. Sci. USA 2006, 103, 1209-1214. [CrossRef] [PubMed]

15. Friedman, D.; Masciangioli, T.; Olson, S. Replacing critical materials with abundant materials. In The Role of the Chemical Sciences in Finding Alternatives to Critical Resources: A Workshop Summary; National Academies Press (US): Washington, DC, USA, 2012; ISBN 978-0-309-25429-8.

16. Hwu, H.H.; Chen, J.G. Surface chemistry of transition metal carbides. Chem. Rev. 2005, 105, 185-212. [CrossRef] [PubMed]

17. Stottlemyer, A.L.; Kelly, T.G.; Meng, Q.; Chen, J.G. Reactions of oxygen-containing molecules on transition metal carbides: Surface science insight into potential applications in catalysis and electrocatalysis. Surf. Sci. Rep. 2012, 67, 201-232. [CrossRef]

18. Levy, R.B.; Boudart, M. Platinum-like behavior of tungsten carbide in surface catalysis. Science 1973, 181, 547-549. [CrossRef] [PubMed]

19. Chen, J.G. Carbide and nitride overlayers on early transition metal surfaces: Preparation, characterization, and reactivities. Chem. Rev. 1996, 96, 1477-1498. [CrossRef] [PubMed] 
20. Villa, A.; Campisi, S.; Giordano, C.; Otte, K.; Prati, L. Mo and W Carbide: Tunable Catalysts for Liquid Phase Conversion of Alcohols. ACS Catal. 2012, 2, 1377-1380. [CrossRef]

21. Patel, M.A.; Baldanza, M.A.S.; Teixeira da Silva, V.; Bridgwater, A.V. In situ catalytic upgrading of bio-oil using supported molybdenum carbide. Appl. Catal. A Gen. 2013, 458, 48-54. [CrossRef]

22. Sousa, L.A.; Zotin, J.L.; Teixeira da Silva, V. Hydrotreatment of sunflower oil using supported molybdenum carbide. Appl. Catal. A Gen. 2012, 449, 105-111. [CrossRef]

23. Oyama, S.T. Preparation and catalytic properties of transition metal carbides and nitrides. Catal. Today 1992, 15, 179-200. [CrossRef]

24. Márquez-Alvarez, C.; Calridge, J.B.; York, A.P.E.; Sloan, J.; Green, M.L.H. Benzene hydrogenation over transition metal carbides. Stud. Surf. Sci. Catal. 1997, 106, 485-490. [CrossRef]

25. Ren, H.; Chen, Y.; Huang, Y.; Deng, W.; Vlachos, D.G.; Chen, J.G. Tungsten carbides as selective deoxygenation catalysts: Experimental and computational studies of converting C3 oxygenates to propene. Green Chem. 2014, 16, 761-769. [CrossRef]

26. Iglesia, E.; Ribeiro, F.H.; Boudart, M.; Baumgartner, J.E. Synthesis, characterization, and catalytic properties of clean and oxygen-modified tungsten carbides. Catal. Today 1992, 15, 307-337. [CrossRef]

27. Ribeiro, F.H.; Boudart, M.; Dalla Betta, R.A.; Iglesia, E. Catalytic reactions of n-Alkanes on $\beta$-W2C and WC: The effect of surface oxygen on reaction pathways. J. Catal. 1991, 130, 498-513. [CrossRef]

28. Urzhuntsev, G.A.; Toktarev, A.V.; Echevskii, G.V.; Delii, I.V.; Vlasova, E.N.; Bukhtiyarova, G.A. Prospects for using Mo- and W-containing catalysts in hydroisomerization: A patent review. Part 1: Catalysts based on molybdenum and tungsten phosphides. Catal. Ind. 2016, 8, 32-39. [CrossRef]

29. Ren, H.; Yu, W.; Salciccioli, M.; Chen, Y.; Huang, Y.; Xiong, K.; Vlachos, D.G.; Chen, J.G. Selective Hydrodeoxygenation of Biomass-Derived Oxygenates to Unsaturated Hydrocarbons using Molybdenum Carbide Catalysts. ChemSusChem 2013, 6, 798-801. [CrossRef] [PubMed]

30. Mai, E.F.; Machado, M.A.; Davies, T.E.; Lopez-Sanchez, J.A.; Teixeira da Silva, V. Molybdenum carbide nanoparticles within carbon nanotubes as superior catalysts for $\gamma$-valerolactone production via levulinic acid hydrogenation. Green Chem. 2014, 16, 4092-4097. [CrossRef]

31. Lee, J.S.; Oyama, S.T.; Boudart, M. Molybdenum carbide catalysts: I. Synthesis of unsupported powders. J. Catal. 1987, 106, 125-133. [CrossRef]

32. Lee, W.-S.; Wang, Z.; Zheng, W.; Vlachos, D.G.; Bhan, A. Vapor phase hydrodeoxygenation of furfural to 2-methylfuran on molybdenum carbide catalysts. Catal. Sci. Technol. 2014, 4, 2340-2352. [CrossRef]

33. Ma, R.; Hao, W.; Ma, X.; Tian, Y.; Li, Y. Catalytic Ethanolysis of Kraft Lignin into High-Value Small-Molecular Chemicals over a Nanostructured $\alpha$-Molybdenum Carbide Catalyst. Angew. Chem. Int. Ed. 2014, 53, 7310-7315. [CrossRef] [PubMed]

34. Choi, J.-S.; Bugli, G.; Djéga-Mariadassou, G. Influence of the Degree of Carburization on the Density of Sites and Hydrogenating Activity of Molybdenum Carbides. J. Catal. 2000, 193, 238-247. [CrossRef]

35. Quiroz, J.; Mai, E.F.; Teixeira da Silva, V. Synthesis of Nanostructured Molybdenum Carbide as Catalyst for the Hydrogenation of Levulinic Acid to $\gamma$-Valerolactone. Top. Catal. 2016, 59, 148-158. [CrossRef]

36. Gosselink, R.W.; Stellwagen, D.R.; Bitter, J.H. Tungsten-Based Catalysts for Selective Deoxygenation. Angew. Chem. Int. Ed. 2013, 52, 5089-5092. [CrossRef] [PubMed]

37. Jongerius, A.L.; Gosselink, R.W.; Dijkstra, J.; Bitter, J.H.; Bruijnincx, P.C.A.; Weckhuysen, B.M. Carbon Nanofiber Supported Transition-Metal Carbide Catalysts for the Hydrodeoxygenation of Guaiacol. ChemCatChem 2013, 5, 2964-2972. [CrossRef]

38. Regmi, Y.N.; Rogers, B.R.; Labbé, N.; Chmely, S.C. Scalable and Tunable Carbide-Phosphide Composite Catalyst System for the Thermochemical Conversion of Biomass. ACS Sustain. Chem. Eng. 2017, 5, 7751-7758. [CrossRef]

39. Santillan-Jimenez, E.; Perdu, M.; Pace, R.; Morgan, T.; Crocker, M. Activated Carbon, Carbon Nanofiber and Carbon Nanotube Supported Molybdenum Carbide Catalysts for the Hydrodeoxygenation of Guaiacol. Catalysts 2015, 5, 424-441. [CrossRef]

40. Han, J.; Duan, J.; Chen, P.; Lou, H.; Zheng, X.; Hong, H. Nanostructured molybdenum carbides supported on carbon nanotubes as efficient catalysts for one-step hydrodeoxygenation and isomerization of vegetable oils. Green Chem. 2011, 13, 2561-2568. [CrossRef]

41. Sun, J.; Zheng, M.; Wang, X.; Wang, A.; Cheng, R.; Li, T.; Zhang, T. Catalytic Performance of Activated Carbon Supported Tungsten Carbide for Hydrazine Decomposition. Catal. Lett. 2008, 123, 150-155. [CrossRef] 
42. Ji, N.; Zhang, T.; Zheng, M.; Wang, A.; Wang, H.; Wang, X.; Chen, J.G. Direct Catalytic Conversion of Cellulose into Ethylene Glycol Using Nickel-Promoted Tungsten Carbide Catalysts. Angew. Chem. Int. Ed. 2008, 47, 8510-8513. [CrossRef] [PubMed]

43. Li, L.; Wang, X.; Zhao, X.; Zheng, M.; Cheng, R.; Zhou, L.; Zhang, T. Microcalorimetric studies of the iridium catalyst for hydrazine decomposition reaction. Thermochim. Acta 2005, 434, 119-124. [CrossRef]

44. Han, J.; Duan, J.; Chen, P.; Lou, H.; Zheng, X. Molybdenum Carbide-Catalyzed Conversion of Renewable Oils into Diesel-like Hydrocarbons. Adv. Synth. Catal. 2011, 353, 2577-2583. [CrossRef]

45. Hollak, S.A.W.; Gosselink, R.W.; van Es, D.S.; Bitter, J.H. Comparison of Tungsten and Molybdenum Carbide Catalysts for the Hydrodeoxygenation of Oleic Acid. ACS Catal. 2013, 3, 2837-2844. [CrossRef]

46. Shi, Y.; Yang, Y.; Li, Y.-W.; Jiao, H. Theoretical study about $\mathrm{Mo}_{2} \mathrm{C}(101)$-catalyzed hydrodeoxygenation of butyric acid to butane for biomass conversion. Catal. Sci. Technol. 2016, 6, 4923-4936. [CrossRef]

47. Yan, K.; Jarvis, C.; Gu, J.; Yan, Y. Production and catalytic transformation of levulinic acid: A platform for speciality chemicals and fuels. Renew. Sustain. Energy Rev. 2015, 51, 986-997. [CrossRef]

48. Alonso, D.M.; Wettstein, S.G.; Dumesic, J.A. Gamma-valerolactone, a sustainable platform molecule derived from lignocellulosic biomass. Green Chem. 2013, 15, 584-595. [CrossRef]

49. Leclercq, L.; Imura, K.; Yoshida, S.; Barbee, T.; Boudart, M. Synthesis of New Catalytic Materials: Metal Carbides of the Group VI B Elements. Stud. Surf. Sci. Catal. 1979, 3, 627-639. [CrossRef]

50. Chen, W.-F.; Wang, C.-H.; Sasaki, K.; Marinkovic, N.; Xu, W.; Muckerman, J.T.; Zhu, Y.; Adzic, R.R. Highly active and durable nanostructured molybdenum carbide electrocatalysts for hydrogen production. Energy Environ. Sci. 2013, 6, 943-951. [CrossRef]

51. Rodella, C.B.; Barrett, D.H.; Moya, S.F.; Figueroa, S.J.A.; Pimenta, M.T.B.; Curvelo, A.A.S.; Teixeira da Silva, V. Physical and chemical studies of tungsten carbide catalysts: Effects of Ni promotion and sulphonated carbon. RSC Adv. 2015, 5, 23874-23885. [CrossRef]

52. Yue, H.; Zhao, Y.; Ma, X.; Gong, J. Ethylene glycol: Properties, synthesis, and applications. Chem. Soc. Rev. 2012, 41, 4218-4244. [CrossRef] [PubMed]

53. Ji, N.; Zhang, T.; Zheng, M.; Wang, A.; Wang, H.; Wang, X.; Shu, Y.; Stottlemyer, A.L.; Chen, J.G. Catalytic conversion of cellulose into ethylene glycol over supported carbide catalysts. Catal. Today 2009, 147, 77-85. [CrossRef]

54. Zhang, Y.; Wang, A.; Zhang, T. A new 3D mesoporous carbon replicated from commercial silica as a catalyst support for direct conversion of cellulose into ethylene glycol. Chem. Commun. 2010, 46, 862-864. [CrossRef] [PubMed]

55. Luo, C.; Wang, S.; Liu, H. Cellulose Conversion into Polyols Catalyzed by Reversibly Formed Acids and Supported Ruthenium Clusters in Hot Water. Angew. Chem. Int. Ed. 2007, 46, 7636-7639. [CrossRef] [PubMed]

56. Xiong, K.; Lee, W.-S.; Bhan, A.; Chen, J.G. Molybdenum Carbide as a Highly Selective Deoxygenation Catalyst for Converting Furfural to 2-Methylfuran. ChemSusChem 2014, 7, 2146-2149. [CrossRef] [PubMed]

57. Lange, J.-P.; van der Heide, E.; van Buijtenen, J.; Price, R. Furfural-A Promising Platform for Lignocellulosic Biofuels. ChemSusChem 2012, 5, 150-166. [CrossRef] [PubMed]

58. Román-Leshkov, Y.; Barrett, C.J.; Liu, Z.Y.; Dumesic, J.A. Production of dimethylfuran for liquid fuels from biomass-derived carbohydrates. Nature 2007, 447, 982-985. [CrossRef] [PubMed]

59. McManus, J.R.; Vohs, J.M. Deoxygenation of glycolaldehyde and furfural on $\mathrm{Mo}_{2} \mathrm{C} / \mathrm{Mo}(100)$. Surf. Sci. 2014, 630, 16-21. [CrossRef]

60. Xiong, K.; Yu, W.; Chen, J.G. Selective deoxygenation of aldehydes and alcohols on molybdenum carbide $\left(\mathrm{Mo}_{2} \mathrm{C}\right)$ surfaces. Appl. Surf. Sci. 2014, 323, 88-95. [CrossRef]

61. Pang, S.H.; Medlin, J.W. Adsorption and Reaction of Furfural and Furfuryl Alcohol on Pd(111): Unique Reaction Pathways for Multifunctional Reagents. ACS Catal. 2011, 1, 1272-1283. [CrossRef]

62. Li, G.; Li, N.; Wang, Z.; Li, C.; Wang, A.; Wang, X.; Cong, Y.; Zhang, T. Synthesis of High-Quality Diesel with Furfural and 2-Methylfuran from Hemicellulose. ChemSusChem 2012, 5, 1958-1966. [CrossRef] [PubMed]

63. Subrahmanyam, A.V.; Thayumanavan, S.; Huber, G.W. C-C Bond Formation Reactions for Biomass-Derived Molecules. ChemSusChem 2010, 3, 1158-1161. [CrossRef] [PubMed]

64. Bej, S.K.; Bennett, C.A.; Thompson, L.T. Acid and base characteristics of molybdenum carbide catalysts. Appl. Catal. A Gen. 2003, 250, 197-208. [CrossRef] 
65. Shi, Y.; Yang, Y.; Li, Y.-W.; Jiao, H. Mechanisms of $\mathrm{Mo}_{2} \mathrm{C}(101)$-Catalyzed Furfural Selective Hydrodeoxygenation to 2-Methylfuran from Computation. ACS Catal. 2016, 6, 6790-6803. [CrossRef]

66. Li, C.; Zhao, X.; Wang, A.; Huber, G.W.; Zhang, T. Catalytic Transformation of Lignin for the Production of Chemicals and Fuels. Chem. Rev. 2015, 115, 11559-11624. [CrossRef] [PubMed]

67. Ma, X.; Ma, R.; Hao, W.; Chen, M.; Yan, F.; Cui, K.; Tian, Y.; Li, Y. Common Pathways in Ethanolysis of Kraft Lignin to Platform Chemicals over Molybdenum-Based Catalysts. ACS Catal. 2015, 5, 4803-4813. [CrossRef]

68. Zakzeski, J.; Bruijnincx, P.C.A.; Jongerius, A.L.; Weckhuysen, B.M. The Catalytic Valorization of Lignin for the Production of Renewable Chemicals. Chem. Rev. 2010, 110, 3552-3599. [CrossRef] [PubMed]

69. Chen, C.-J.; Lee, W.-S.; Bhan, A. $\mathrm{Mo}_{2} \mathrm{C}$ catalyzed vapor phase hydrodeoxygenation of lignin-derived phenolic compound mixtures to aromatics under ambient pressure. Appl. Catal. A Gen. 2016, 510, 42-48. [CrossRef]

70. Cheng, S.; Wilks, C.; Yuan, Z.; Leitch, M.; Xu, C. (Charles) Hydrothermal degradation of alkali lignin to bio-phenolic compounds in sub/supercritical ethanol and water-ethanol co-solvent. Polym. Degrad. Stab. 2012, 97, 839-848. [CrossRef]

71. Engelhardt, J.; Lyu, P.; Nachtigall, P.; Schüth, F.; García, Á.M. The Influence of Water on the Performance of Molybdenum Carbide Catalysts in Hydrodeoxygenation Reactions: A Combined Theoretical and Experimental Study. ChemCatChem 2017, 9, 1985-1991. [CrossRef]

72. Guo, H.; Zhang, B.; Li, C.; Peng, C.; Dai, T.; Xie, H.; Wang, A.; Zhang, T. Tungsten Carbide: A Remarkably Efficient Catalyst for the Selective Cleavage of Lignin C-O Bonds. ChemSusChem 2016, 9, 3220-3229. [CrossRef] [PubMed]

73. Guo, H.; Zhang, B.; Qi, Z.; Li, C.; Ji, J.; Dai, T.; Wang, A.; Zhang, T. Valorization of Lignin to Simple Phenolic Compounds over Tungsten Carbide: Impact of Lignin Structure. ChemSusChem 2017, 10, 523-532. [CrossRef] [PubMed]

74. Chang, A.C.C.; Chang, H.-F.; Lin, F.-J.; Lin, K.-H.; Chen, C.-H. Biomass gasification for hydrogen production. Int. J. Hydrogen Energy 2011, 36, 14252-14260. [CrossRef]

75. Kaewpanha, M.; Guan, G.; Ma, Y.; Hao, X.; Zhang, Z.; Reubroychareon, P.; Kusakabe, K.; Abudula, A. Hydrogen production by steam reforming of biomass tar over biomass char supported molybdenum carbide catalyst. Int. J. Hydrogen Energy 2015, 40, 7974-7982. [CrossRef]

76. Darujati, A.R.; LaMont, D.C.; Thomson, W.J. Oxidation stability of $\mathrm{Mo}_{2} \mathrm{C}$ catalysts under fuel reforming conditions. Appl. Catal. A Gen. 2003, 253, 397-407. [CrossRef] 